\title{
Atractis thapari (Nematoda, Atractidae) parasitizing Chelonoidis carbonarius and $C$. denticulatus (Testudinidae) in the state of Piauí, Brazil
}

\author{
Atractis thapari (Nematoda, Atractidae) parasitando Chelonoidis carbonarius e C. denticulatus (Testudinidae) \\ no estado do Piauí, Brasil
}

Anangela Ravena da Silva Leal'; Simone Mousinho Freire ${ }^{1,2}$; Marcelo Knoff*; ${ }^{3 *}$ Delir Corrêa Gomes; Jeannie Nascimento dos Santos ${ }^{4}$; Ivete Lopes de Mendonça ${ }^{1}$

\author{
${ }^{1}$ Laboratório de Sanidade Animal, Centro de Ciências Agrárias, Universidade Federal do Piauí - UFPI, Teresina, PI, Brasil \\ ${ }^{2}$ Laboratório de Zoologia e Biologia Parasitária, Universidade Estadual do Piauí - UEPI, Teresina, PI, Brasil \\ ${ }^{3}$ Laboratório de Helmintos Parasitos de Vertebrados, Instituto Oswaldo Cruz, Fundação Oswaldo Cruz - FIOCRUZ, Rio de Janeiro, \\ RJ, Brasil \\ ${ }^{4}$ Laboratório de Biologia Celular e Helmintologia “Profa. Dra. Reinalda Marisa Lanfredi”, Instituto de Ciências Biológicas, \\ Universidade Federal do Pará - UFPA, Belém, PA, Brasil
}

Received October 5, 2017

Accepted January 22, 2018

\begin{abstract}
Atractis thapari Petter, 1966, an atractid nematode, was collected parasitizing the large intestine of tortoises of the species Chelonoidis carbonarius (Spix, 1824) $(C c)$ and C. denticulatus (Linnaeus, 1766) (Cd) (Testudinidae) in the Zoobotanical Park of the municipality of Teresina, state of Piauí, Brazil. Taxonomic identification was based on morphological and morphometrical features, and using bright-field and scanning electron microscopy. The present study adds new observations on the morphology of $A$. thapari, mainly relating to mouth papillae, the excretory pore, deirids, and male and female posterior ends. The parasitic indices of prevalence (P), mean intensity (MI), mean abundance (MA) and range of infection (RI) for $A$. thapari in these two tortoise species were: $\mathrm{P}=100 \%, \mathrm{MI}=154,667, \mathrm{MA}=154,667$, $\mathrm{RI}=5,500-588,500(C c) ; \mathrm{P}=100 \%, \mathrm{MI}=93,639, \mathrm{MA}=93,639, \mathrm{RI}=1,000-224,500(C d)$. This report confirms the occurrence of $A$. thapari in Neotropical region, South America, Brazil, and extends its occurrences to a new host, the tortoise $C$. carbonarius. Adjustment of host management with the aim of improving hygiene and health conditions is suggested.
\end{abstract}

Keywords: Nematode, Atractidae, Atractis thapari, Testudinidae, Brazil.

\section{Resumo}

Atractis thapari Petter, 1966, um nematoide atractídeo, foi coletado parasitando o intestino grosso de jabutis, Chelonoidis carbonarius (Spix, 1824) (Cc) e C. denticulatus (Linnaeus, 1766) (Cd) no Parque Zoobotânico, município de Teresina, estado do Piauí, Brasil. A identificação taxonômica foi baseada nos caracteres morfológicos e morfométricos usando microscopias de campo claro e eletrônica de varredura. O presente estudo adiciona novas observaçóes na morfologia, principalmente relacionadas as papilas bucais, poro excretor, deirídeos, e extremidade posterior de machos e fêmeas. Os índices parasitários de prevalência (P), intensidade média (IM), abundância média (AM) e amplitude de variação de infecção (AI) de $A$. thapari em ambos jabutis foram $\mathrm{P}=100 \%, \mathrm{IM}=154.667, \mathrm{AM}=154.667, \mathrm{AI}=5.500-588.500(C c)$; $\mathrm{P}=100 \%, \mathrm{I} M=93.639, \mathrm{AM}=93.639, \mathrm{AI}=1.000-224.500(C d)$. Este registro confirma a ocorrência de $A$. thapari na regiāo Neotropical, América do Sul, Brasil, e expande a um novo hospedeiro, o jabuti $C$. carbonarius. É sugerido um ajuste no manejo dos hospedeiros objetivando melhora das suas condições higiênico sanitárias.

Palavras-chave: Nematode, Atractidae, Atractis thapari, Testudinidae, Brasil.

\footnotetext{
*Corresponding author: Marcelo Knoff. Laboratório de Helmintos

Parasitos de Vertebrados, Instituto Oswaldo Cruz, Fundação Oswaldo Cruz -

FIOCRUZ, Av. Brasil, 4365, Manguinhos, CEP 21040-900, Rio de Janeiro,

RJ, Brasil. e-mail: knoffm@ioc.fiocruz.br
} 


\section{Introduction}

The tortoise Chelonoidis carbonarius (Spix, 1824) occurs in the southernmost part of Central America (southeastern Panama), part of the northern half of South America (west of the Andes in Chocó, Colombia, and east of the Andes in Colombia, Venezuela, the Guianas and northeastern Brazil, south to Rio de Janeiro, and west to eastern Bolivia, Paraguay and northern Argentina), and in Trinidad and some islands of the Lesser Antilles. The tortoise Chelonoidis denticulatus (Linnaeus, 1766) occurs in the northern half of South America east of the Andes, and, also, south to southern Brazil and on the island of Trinidad (FRITZ \& HAVAŠ, 2007; RUEDA-ALMONACID et al., 2007).

As a result of a survey for parasitic helminths, two nematode species were recovered from C. carbonarius and C. denticulatus, which were kept at the Zoobotanical Park, municipality of Teresina, state of Piauí, Brazil. One of the species was recently identified as a strongylid known as Chapiniella variabilis (Chapin, 1924) (FREIRE et al., 2017), while the other was an atractid. The present study aims to: (1) taxonomically identify the atractid nematode based on morphological and morphometrical features, and using bright-field and scanning electron microscopy; (2) calculate the parasitic indices, of prevalence, mean intensity, mean abundance and range of infection; and (3) point out the relevance of this species to the health of these reptiles in captivity.

\section{Materials and Methods}

Between June 2014 and June 2015, a total of 12 adult tortoises (six $C$. carbonarius and six $C$. denticulatus, three males and three females of each) at the Zoobotanical Park, municipality of Teresina, state of Piauí, Brazil (0504'10" S; 42076'87” W) were examined. They formed part of a group of 102 individuals of $C$. carbonarius and 40 of $C$. denticulatus that were living under confinement in the same area of captivity. All of the specimens were from the state of Piauí, and had been seized by the Brazilian Institute of Environment and Renewable Natural Resources (IBAMA) or the state environmental police, or donated by private individuals. The tortoises were subjected to stool analysis by means of the Hoffmann and Willis methods (KNOFF \& GOMES, 2012), with the twelve individuals with the highest rates of parasitism being chosen for sacrifice. The chelonians were identified based on Rueda-Almonacid et al. (2007), and the combinations of specific epithets are according to the nomenclatural adjustments suggested by Olson \& David (2014) for the genus Chelonoidis Fitzinger, 1835 and accepted by Costa \& Bérnils (2015). Animals were sacrificed by first sedating them with an intramuscular application of an association ketamine (15 mg/kg) and xylazine $(10 \mathrm{mg} / \mathrm{kg})$. Forty-five minutes later, an overdose of $25 \mathrm{mg} / \mathrm{kg}$ of $1 \%$ sodium thiopental was applied intravenously.

The sacrificed chelonians were then necropsied. The nematodes recovered through this process were placed in Petri dishes with $0.65 \%$ $\mathrm{NaCl}$ solution, fixed in hot AFA (glacial acetic acid, formaldehyde and $70 \%$ ethanol in the proportions of 2:3:95), preserved in a solution of $70 \%$ ethanol plus $5 \%$ glycerin and clarified with
Amman's lactophenol. Some specimens were mounted in Canada balsam as described by Knoff \& Gomes (2012).

The nematodes were identified taxonomically in accordance with De Ley \& Blaxter (2004), Chabaud (2009) and Gibbons (2010). Morphometric analyses were performed using an Olympus BX41 bright-field microscope with a drawing tube attached. Measurements are shown as means $(\mathrm{mm})$ with the ranges in parentheses, unless otherwise indicated. Images were obtained using a Canon digital camera (Power Shot A640) coupled to a Zeiss Axiophot microscope.

For topographic description of the cuticular surface, nematodes were analyzed using scanning electron microscopy (SEM). Samples were fixed in $2.5 \%$ glutaraldehyde with $0.1 \mathrm{M}$ sodium cacodylate buffer ( $\mathrm{pH} 7.4$ ), postfixed in $1 \%$ osmium tetroxide, dehydrated in an ethanol series, dried using the $\mathrm{CO}_{2}$ critical point drying method and coated in gold. The prepared samples were then examined and photographed using a Vega-3 scanning electron microscope (Tescan) with $15 \mathrm{kV}$ acceleration voltage.

Prevalence (P), mean intensity (MI), mean abundance (MA), and range of intensity of infection (RI) were calculated as described by Bush et al. (1997). Representative specimens (vouchers) were deposited in the Helminthological Collection of the Oswaldo Cruz Institute (CHIOC), Rio de Janeiro, state of Rio de Janeiro, Brazil. This study was authorized by the Ethics Committee for Animal Experimentation of the Federal University of Piauí, municipality of Teresina, state of Piauí, Brazil, under number 09/2015, and by the Biodiversity Authorization and Information System (SISBIO), under number 44782-1, emitted in June/16/2014.

\section{Results}

All hosts were parasitized with adult nematodes (prevalence $=100 \%$ ). A total of 1,489,833 adult nematodes were collected, including 928,000 from six specimens of $C$. carbonarius and 561,833 from six of $C$. denticulatus. All nematodes were alive and showed high motility.

Rhabditida Chitwood, 1933

Spirurina Raillet and Henry, 1915

Ascaridomorpha De Ley and Blaxter, 2002

Cosmocercoidea Skrjabin and Schikhobalova, 1951

Atractidae Travassos, 1919

Atractis Dujardin, 1945

Atractis thapari Petter, 1966 (Figure 1-12)

Syn. A. dactyluris sensu Thapar, 1925

General description

A short, thin nematode with a cylindrical body tapering posteriorly and truncate anteriorly. Head not distinct from the rest of the body. Mouth opening surrounded by three lips, one dorsal and two sub-ventral, divided into six small ridges of marginally bi-lobed radiating lips. Mouth papillae small, inner circlet with four rod-like papillae, outer circlet with four spherical papillae; the two sub-ventral lips each possess an elongate lateral amphid. Buccal capsule absent. Esophagus dived into two portions, a thickened, sclerotized anterior portion and thinner posterior portion that terminates in a valvular bulb. Anterior end of esophagus tri-radiate forming a short pharynx. Nerve ring slightly posterior to posterior 

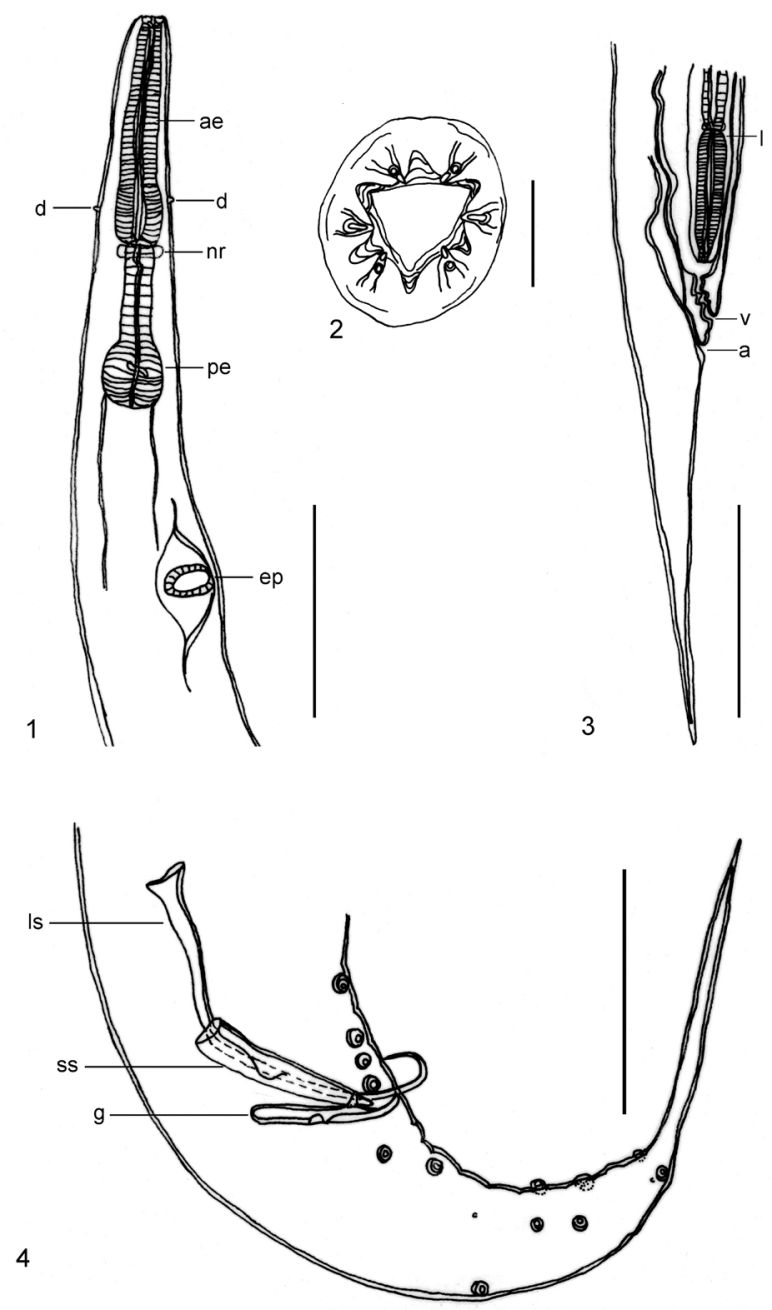

Figures 1-4. Atractis thapari from Chelonoidis carbonarius. 1. Female, anterior end, anterior esophagus (ae), deirids (d), nerve ring (nr), posterior esophagus (pe), and excretory pore (ep), in lateral view. 2. Female, cephalic end, in apical view. 3. Female, posterior end, vulva (v), anus (a), and larva, in lateral view. 4. Male, posterior end, dissimilar spicules, long spicule-lanceolate (ls), short spicule-lagenoid (ss) and gubernaculum (g) with ventrolateral spurs, in lateral view. Scale bars: 1 and $3=400 \mu \mathrm{m} ; 2=20 \mu \mathrm{m} ; 4=200 \mu \mathrm{m}$.
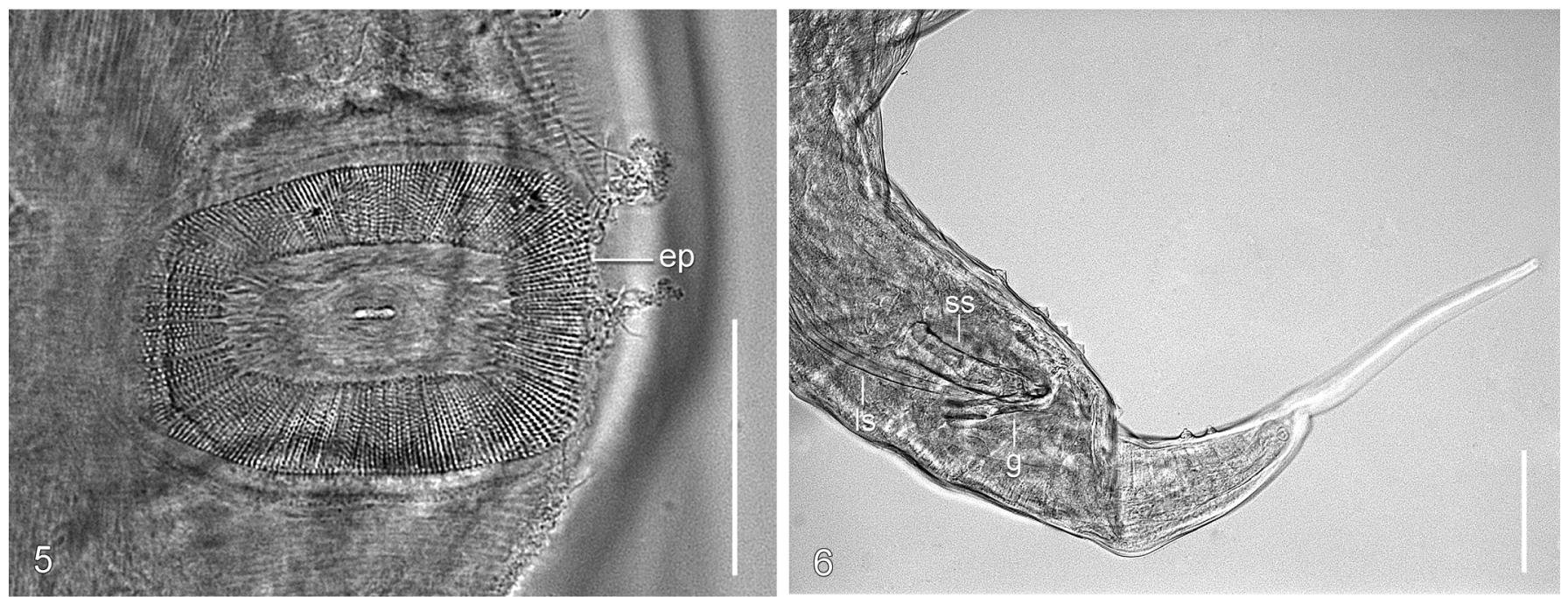

Figures 5-6. Atractis thapari from Chelonoidis carbonarius observed by light microscopy. 5. Female, detail of excretory pore (ep), in ventral view. 6. Male, posterior end, dissimilar spicules, long spicule-lanceolate (ls), short spicule-lagenoid (ss) and gubernaculum (g), with ventrolateral spurs, in lateral view. Scale bars: $5=50 \mu \mathrm{m} ; 6=100 \mu \mathrm{m}$. 

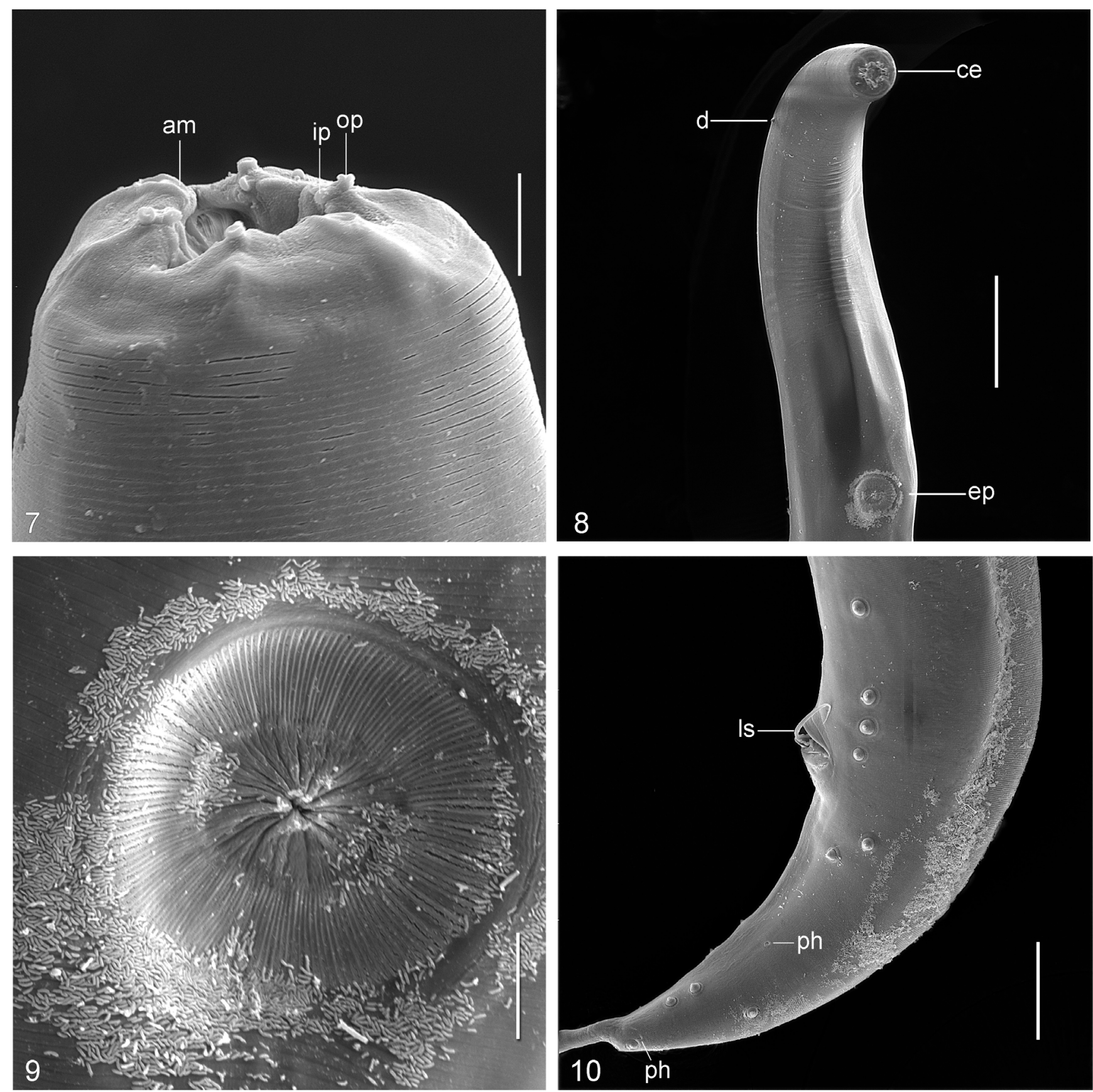

Figures 7-10. Scanning electron micrographs of Atractis thapari from Chelonoidis carbonarius. 7. Female, cephalic end, amphid (am), cephalic papilla of inner circle (ip) and cephalic papilla of outer circle (op), in ventrolateral view. 8. Female, anterior end, cephalic end (ce), deirid (d) and excretory pore (ep), in ventral view. 9. Female, detail of excretory pore, in ventral view. 10. Male, posterior end, long spicule-lanceolate (ls) partially extroverted, 10 pairs of caudal papillae with two pairs of phasmids (ph), in lateral view. Scale bars: 7 and $9=10 \mu \mathrm{m} ; 8=100 \mu \mathrm{m}$; $10=50 \mu \mathrm{m}$.

end of esophageal corpus. Excretory pore surrounded by a different cuticular pattern, forming a sucker-like structure, posterior to the second portion of the esophagus. Deirids small, somewhat anterior to level of nerve ring, near end of anterior portion of the esophagus. Body of males with posterior third spirally coiled or slightly curved, terminating in a long, sharply-pointed conical tail, becoming thinner after last caudal papillae pair. Precloacal, adcloacal and postcloacal papillae present, phasmids present.
Male caudal papillae distribution pattern: three precloacal pairs, one adcloacal pair, six postcloacal pairs. Precloacal and adcloacal papillae located ventrally. Postcloacal papillae distribution pattern: first and sixth pairs located laterally; second, fourth and fifth pairs located ventrally; third pair located almost dorsally. Tail with two pairs of phasmids posterior to the cloaca; first phasmid pair located ventrally between second and third pairs of postcloacal papillae and second phasmid pair located laterally just anterior to sixth pair of 

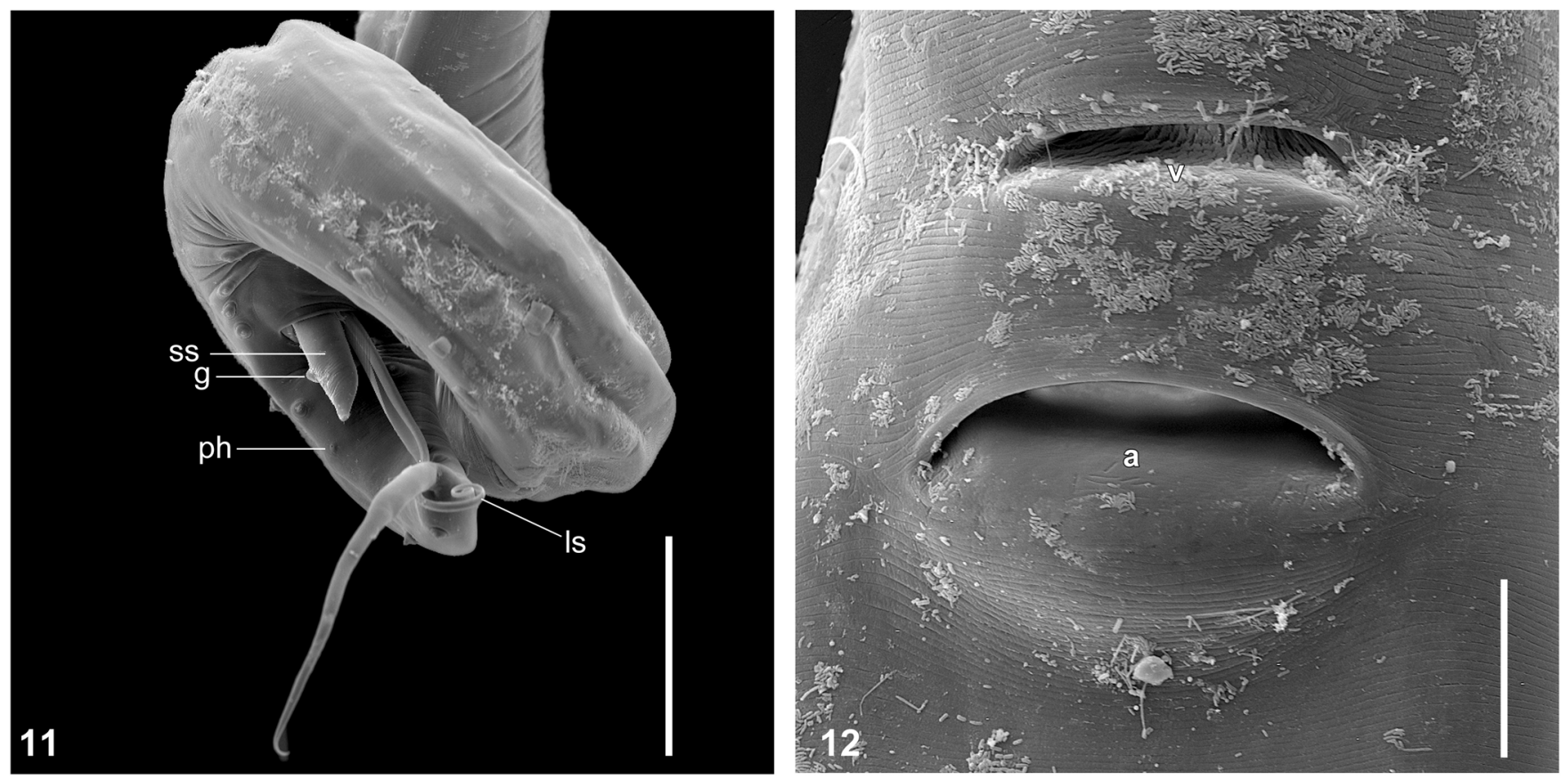

Figures 11-12. Scanning electron micrographs of Atractis thapari from Chelonoidis carbonarius. 11. Male, posterior end spiraled, long spicule-lanceolate (ls), short spicule-lagenoid (ss) and partially extroverted gubernaculum (g), caudal papillae with the anterior phasmid (ph) conspicuous, in ventral and dorsal views. 12. Female, posterior end, vulva (v) and anus (a), in lateral view. Scale bars: $11=100 \mu \mathrm{m} ; 12=20 \mu \mathrm{m}$.

postcloacal papillae. Unequal and dissimilar spicules (small spicule, lagenoid, and long spicule, lanceolate), and strongly sclerotized and lightly-curved gubernaculum supporting ventrolateral spurs. Body of female straight, terminating in a long, straight, conical tail; vulva just anterior to anus. Females monodelphic, viviparous, and with uterus containing fully developed larvae (3-4) in some specimens.

Males from C. carbonarius (10 vouchers): length 5.595 (5.375-6.000); width at level of esophageal-intestinal junction $0.223(0.200-0.240)$. Anterior esophagus sclerotized 0.413 (0.395-0.425); posterior esophagus $0.317(0.295-0.350)$, bulb length $0.132(0.115-0.180)$, bulb width $0.144(0.130-0.150)$. Excretory pore 1.161 (1.080-1.240) from anterior end. Tail length 0.615 (0.550-0.675). Left spicule lanceolate $384 \mu \mathrm{m}(370-395 \mu \mathrm{m})$ in length; right spicule lagenoid (bottle-shaped) $148 \mu \mathrm{m}(140-155 \mu \mathrm{m})$ in length. Gubernaculum $131 \mu \mathrm{m}(120-140 \mu \mathrm{m})$ long.

Females from C. carbonarius (10 vouchers): length 5.194 (4.65-5.72), width at level of esophageal-intestinal junction 0.236 (0.210-0.275). Anterior esophagus 0.439 (0.400-0.490), posterior esophagus 0.344 (0.300-0.395), bulb length 0.156 (0.150-0.170), bulb width $0.162(0.145-0.175)$. Excretory pore $1.155(0.990-1.190)$ from anterior end. Vulva non salient 0.055 (0.040-0.097) anterior to anus. Vagina short, 0.067 (0.060-0.085) long, joins a single uterus. Tail $0.756(0.660-0.855)$ long. Larva length 1.990-2.220 (1.95) and width 0.060-0.100 (0.082) $(\mathrm{n}=10)$.

Males from $C$. denticulatus (10 vouchers): length 5.271 (5.01-5.61), width at level of esophageal-intestinal junction 0.195 (0.160-0.240). Anterior esophagus sclerotized 0.391 (0.360-0.425), posterior esophagus 0.298 (0.275-0.325), bulb length $0.135(0.125-0.145)$, bulb width $0.128(0.115-0.145)$.
Excretory pore $1.025(0.950-1.120)$ from anterior end. Tail length $0.550(0.425-0.665)$. Left spicule lanceolate $350 \mu \mathrm{m}(250-415 \mu \mathrm{m})$ long; right spicule lagenoid (bottle-shaped) $140 \mu \mathrm{m}(135-145 \mu \mathrm{m})$ long. Gubernaculum $129 \mu \mathrm{m}(125-135 \mu \mathrm{m})$ long.

Females from $C$. denticulatus (10 vouchers): length 5.665 (5.100-6.120), width at level of esophageal-intestinal junction 0.231 (0.200-0.270). Anterior esophagus 0.392 (0.350-0.420), posterior esophagus $0.310(0.270-0.330)$, bulb length 0.146 (0.130-0.155), bulb width $0.143(0.120-0.165)$. Excretory pore $1.038(0.955-1.135)$ from anterior end. Vulva non-salient 0.100 (0.045-0.060) anterior to anus. Vagina short, 0.120 (0.060-0.072) long, joins a single uterus. Tail 0.787 (0.730-0.850) long. Larva length 1.730-2.300 (1.960) and width 0.060-0.070 (0.064) (n=10).

Hosts: $C$. carbonarius $(C c)$ and $C$. denticulatus $(C d)$.

Locality: Zoobotanical Park, municipality of Teresina, state of Piauí, Brazil.

Parasitic indices: $\mathrm{P}=100 \%, \mathrm{MI}=154,667, \mathrm{MA}=154,667$, $\mathrm{RI}=5,500-58,500(C c) ; \mathrm{P}=100 \%, \mathrm{MI}=93,639, \mathrm{MA}=93,639$, $\mathrm{RI}=1,000-224,500(C d)$.

Infection site: large intestine of both hosts.

Deposition of voucher specimens: CHIOC 38138 (7 females) and CHIOC 38139 (8 males) (Cc) wet material; CHIOC 38140 (6 females) and CHIOC 38141 (7 males) (Cd) wet material.

\section{Remarks}

The collected nematode specimens are in accordance with the features of the genus Atractis as revised by Bursey \& Flanagan (2002), who proposed that only species with a lanceolate spicule, 
a lagenoid spicule and a gubernaculum should be assigned to this genus. Since this conception of the genus Atractis (BURSEY \& FLANAGAN, 2002), species have been reported from a variety of different biogeographic realms (IKROMOV \& CHO, 2004; TRAVERSA et al., 2005; ROCA et al., 2007; AL-BARWARI \& SAEED, 2007; MCALLISTER et al., 2010; BURSEY \& BROOKS, 2011).

The specimens collected in the present study were identified as $A$. thapari (PETTER, 1966), due to of their similarity to the description of this species in body and tail length; presence of lanceolate and lagenoid spicules, and a gubernaculum; and papillae pattern. The papillae arrangement described in the original description, of the former caudal papillae pairs being well distanced from the subsequent three pairs, with the latter three pairs being described as "circumcloacal papillae", is the same arrangement observed in the specimens of the present study (THAPAR, 1925).

Historically, Thapar (1925) identified adult specimens of this taxa recovered from the stomach of an individual of Testudo tabulata ( = C. denticulatus) which had been collected from South America and that had died on the Gardens of the Zoological Society of London, as A. dactyluris (Rudolphi, 1819). After analyzing these specimens of $A$. dactyluris sensu Thapar, 1925, Petter (1966), described them as a new species, reporting that it was unlikely that this species will be found in a great variety of geographical areas. Petter (1966) also used tail length to differentiated the new species from the other species of Atractis, and wrote at page 29:

“[...] la longuer des queues, en particulier de la pointe caudale au-delàs des dernières papilles post-cloacales chez le male. [...]; [...] enfin, elle attaint une très grande taille chez $A$. thapari $(247 \mu)$ et $A$. morinae [...]." ("[...] the length of the tails, especially the caudal tip beyond the last post-cloacal papillae in the male $[. .] ;.[. .$.$] finally, it attains a$ very large size in $A$. thapari $(247 \mu)$ and $A$. morinae [...]").

Among the 14 known species of Atractis, those that most resemble $A$. thapari with regard to body length, lagenoid and lanceolate spicules, gubernaculum, and long sharply-pointed conical tail are A. morinae Baer, 1936, A. marquezi Bursey \& Flanagan, 2002, A. vidali González-Solís \& Moravec, 2002 and A. costaricaensis Gibbons \& Platt, 2006 (BAER, 1936; BURSEY \& FLANAGAN, 2002; GONZÁLEZ-SOLÍS \& MORAVEC, 2002; GIBBONS \& PLATT, 2006).

Atractis morinae is a parasite of Testudo radiata Shaw, 1802 collected on the island of Madagascar, Africa. It also possesses a long, sharp tail, but the arrangement of caudal papillae is different from that of $A$. thapari. Atractis marquezi is a parasite of Geochelone nigrita (Duméril \& Bibron, 1835) collected on Isla Santa Cruz, Galapagos, Ecuador, but differs from $A$. thapari in having a shorter distance between the esophageal bulb and the excretory pore, and in the arrangement of caudal papillae. Atractis vidali is parasite of two cichlid fish species collected in southern Mexico, and differs from A. thapari in having a gubernaculum without ventrolateral spurs, and in the arrangement of caudal papillae. Atractis costaricensis is a parasite of the turtle Rhinoclemmys pulcherrima (Gray, 1855) in Costa Rica, and possesses body measurements and structures, such as spicules and gubernaculum, somewhat smaller then the other species and specimens of this study, and the arrangement of caudal papillae differs, mainly with regard to the precloacal papillae (BAER,
1936; BURSEY \& FLANAGAN, 2002; GONZÁLEZ-SOLÍS \& MORAVEC, 2002; GIBBONS \& PLATT, 2006).

Based on observations by bright-field and scanning electron microscopy, new details with regard to the morphology of Atractis thapari were recorded. On the anterior end, the morphological features and location of inner and outer papillae and of the amphids on the two subventral lips were described, as were the six sudivisions of the dorsal lip on the cephalic end, and excretory pore surrounded by a different cuticular pattern, forming a sucker-like structure. On the posterior end of the male the presence of an additional pair of phasmids among the postcloacal papillae, and the striated surface of the lagenoid spicule and the smooth surface of the lanceolated spicule, when the spicules are extroverted, were described. Analyzing the specimens of present study, it was possible to add to the original description of Thapar (1925) and Petter (1966), the presence of one more pair of post-cloacal papillae and of one pair phasmids among the postcloacal papillae.

Morphological and morphometrical analysis allowed us to identify 20 Atractis sp. specimens that were deposited in CHIOC by Dr. Lauro P. Travassos, in March 25, 1955, collected from Testudo sp. (= Chelonoides sp.) from the state of Maranhão, Brazil [slides numbers CHIOC 21410 a-c (5 males and 8 females) and CHIOC 21412 a-b (1 male and 6 females)], as $A$. thapari thus extending the known geographical occurrence of this species in Brazil.

\section{Discussion}

Some species of Atractis have been recently reported from South America, such as Atractis sp. and A. marquezi in $C$. denticulatus from Perú (JULCA et al., 2014; CHÁVEZ et al., 2015), and Atractis sp. in C. carbonarius and C. denticulatus from Venezuela (MATA et al., 2014). Atractis sp. was also reported in Chelonoides spp. of Galapagos Islands, which were supposedly identified as A. marquezi (FOURNIÉ et al., 2015). Therefore, the occurrence of $A$. thapari in $C$. denticulatus remains restricted to that of original description, where the tortoise specimen of $C$. denticulatus, from which the type material had been obtained, was reported to have been collected from South America (without indicating an exact location) and died on the Gardens of the Zoological Society of London (THAPAR, 1925). Therefore this report confirms the occurrence of this parasite in South America, specifically in Brazil, and adds the tortoise $C$. carbonarius as a new host species.

In the present study, the parasitic indices of $A$. thapari were high in both host species. Considering that the individuals examined were selected from a group of 142 tortoises living in the same area of captivity (covering $225 \mathrm{~m}^{2}$ ), and the fact that species of Atractis have a direct life cycle (MADER, 2006), this nematode could be transmitted among this tortoises. According to Primack \& Rodrigues (2001), grouping hosts together may cause greater direct pressure for the occurrence of parasites and diseases. Placing host populations in small areas may decrease habitat quality and food availability, which will give rise to low nutritional values, malnourished animals and, consequently, increased susceptibility to infections. Groupings of large numbers of individuals can lead to social stress, followed by decreased disease resistance in 
the populations. Recently, Freire et al. (2017) suggested that the nematode Chapiniella variabilis is also a parasite of the same hosts of the same area. Adjustments to host management should be made to minimize these parasitic infections, including the application of anthelmintics and reducing the number of individuals per $\mathrm{m}^{2}$, thereby increasing the space available, avoiding higher parasitic indices, and improving the health conditions for these reptiles at the Zoobotanical Park of Teresina.

\section{Acknowledgements}

The authors would like to thank Dr. Elane Guerreiro Giese from the Laboratório de Histologia e Embriologia Animal, Instituto de Saúde e Produçáo Animal, Universidade Federal Rural da Amazônia, for her kind assistence with scanning electron microscopy (VEGA 3/TESCAN); Ricardo Baptista Schmidt from the Serviço de Produção e Processamento de Imagem Científica, IOC, FIOCRUZ, for processing the figures; and Conselho Nacional de Desenvolvimento Científico e Tecnológico (CNPq) for partial financial support.

\section{References}

Al-Barwari SE, Saeed I. On the helminth fauna of some Iraqi reptiles. Turkiye Parazitol Derg 2007; 31(4): 330-336. PMid:18224629.

Baer JG. Une nouvelle espece d'oxyure, Atractis morinae n. sp., chez une tortue africaine. Rev Parasitol Clin Lab 1936; 2: 277-281.

Bursey CR, Brooks DR. Nematode parasites of five species of turtles from the Area de Conservacion Guanacaste, Costa Rica, with description of a new species of Falcastrua. Comp Parasitol 2011; 78(1): 107-119. http:// dx.doi.org/10.1654/4431.1.

Bursey CR, Flanagan JP. Atractis marquezi n. sp. (Nematoda: Atractidae) and a revision of Atractis Dujardin, 1845, sensu Baker, 1987. J Parasitol 2002; 88(2): 320-324. PMid:12054005. http://dx.doi.org/10.1645/00223395(2002)088[0320:AMNSNA]2.0.CO;2.

Bush AO, Lafferty KD, Lotz JM, Shostak AW. Parasitology meets ecology on its own terms: Margolis et al. revisited. J Parasitol 1997; 83(4): 575583. PMid:9267395. http://dx.doi.org/10.2307/3284227.

Chabaud A. Ascaridida. Cosmocercoidea, Seuratoidea and Heterakoidea. In: Anderson RC, Chabaud AG, Willmott S. Keys to the nematode parasites of vertebrates. Wallingford: CABI Publishing; 2009. p. 248-308. Archival volume.

Chávez LC, Serrano-Martínez E, Tantaleán MV, Quispe MH, Casas GCV. Parásitos gastrointestinales en reptiles en cautiverio en Lima metropolitana. Rev Investig Vet Peru 2015; 26(1): 127-134. http://dx.doi. org/10.15381/rivep.v26i1.10909.

Costa HC, Bérnils RS. Mudanças taxonômicas. Herpetol Bras 2015; 4(3): 75-93.

De Ley P, Blaxter M. A new system for Nematoda: combining morphological characters with molecular trees, and translating clades into ranks and taxa. In: Cook R, Hunt DJ, editors. Nematology Monographs and Perspectives. Leiden: EJ Brill; 2004. p. 633-653, vol. 2.
Fournié G, Goodman SJ, Cruz M, Cedeño V, Vélez A, Patiño L, et al. Biogeography of parasitic nematode communities in the galápagos giant tortoise: implications for conservation management. PLoS One 2015; 10(9): e0135684. http://dx.doi.org/10.1371/journal.pone.0135684.

Freire SM, Leal ARS, Knoff M, Gomes DC, Santos JN, Giese EG, et al. Chapiniella variabilis (Nematoda) parasitizing Chelonoidis carbonarius and $C$. denticulatus (Testudinidae) in the state of Piauí. Rev Bras Parasitol Vet 2017; 26(3): 359-365. PMid:28327883. http://dx.doi.org/10.1590/ s1984-29612017011.

Fritz U, Havaš P. Checklist of chelonians of the world. Vertebr Zool 2007; 57(2): 149-368.

Gibbons LM, Platt TR. Rhinoclemmysneman. g. and three new species of nematodes of the family Atractidae (Cosmocercoidea), with notes on the helminth fauna of Rhinoclemmys pulcherrima (Testudines: Bataguridae) in Costa Rica. J Helminthol 2006; 80(4): 333-340. PMid:17125541. http://dx.doi.org/10.1017/JOH2006360.

Gibbons LM. Keys to the nematode parasites of vertebrates. Wallingford and Cambridge: CABI Publishing; 2010. Suplementary volume.

González-Solís D, Moravec F. A new atractid nematode, Atractis vidali sp. n. (Nematoda: Atractidae), from cichlid fishes in Southern Mexico. Folia Parasitol 2002; 49(3): 227-230. PMid:12418816. http://dx.doi. org/10.14411/fp.2002.041.

Ikromov EF, Cho MR. On new representatives of the helminth fauna of reptiles (Testudines and Sauria) in Uzbekistan. J Asia Pac Entomol 2004; 7(1): 13-17. http://dx.doi.org/10.1016/S1226-8615(08)60196-X.

Julca R, Casas EA, Chavera AC, Sánchez LP, Sánchez NP, Batalla LL. Descripción anatomopatológica de lesiones por helmintos gastrointestinales en tortugas motelo (Chelonoidis denticulata). Rev Investig Vet Peru 2014; 25(1): 37-50. http://dx.doi.org/10.15381/rivep.v25i1.8466.

Knoff M, Gomes DC. Metodologia básica para coleta e processamento de helmintos parasitos. In: Molinaro EM, Caputo LFG, Amendoeira MRR. Conceitos e métodos para formaçāo de profissionais em laboratórios de saúde. Rio de Janeiro: EPSJV; 2012. p. 251-281, vol. 5.

Mader DR. Reptile medicine and surgery. 2nd ed. Philadelphia: WB Saunders Co; 2006.

Mata AP, Aguirre A, Pińango JQ, Olivares JL, Camacho AB, Bautista $\mathrm{N}$, et al. Parasitic nematode infection in the south american red-footed tortoise Geochelone carbonaria from Upata, Bolívar, Venezuela. Neotrop Helminthol 2014; 8(2): 251-257.

McAllister CT, Bursey CR, Freed PS. Helminth parasites of selected amphibians and reptiles from the Republic of Ecuador. Comp Parasitol 2010; 77(1): 52-66. http://dx.doi.org/10.1654/4402.1.

Olson SL, David N. The gender of the tortoise genus Chelonoidis Fitzinger, 1835 (Testudines: Testudinidae). Proc Biol Soc Wash 2014; 126(4): 393 394. http://dx.doi.org/10.2988/0006-324X-126.4.393.

Petter AJ. Équilibre des espèces dans les populations de nématodes parasites du colon des tortues terrestres. Paris: Muséum national d'Histoire naturelle; 1966. 252 p. (Mémoires du Muséum national d'Histoire naturelle, Sér. A - Zoologie (1950-1992), vol. 39, n. 1)

Primack BR, Rodrigues E. Ameaças a diversidade biológica. In: Primack RB, Rodrigues E. Biologia da conservaçâo. Londrina: Vida; 2001. p. 69-133.

Roca V, García G, Montesinos A. Gastrointestinal helminths found in the three freshwater turtles (Erymnochelys madagascariensis, Pelomedusa 
subrufa and Pelusios castanoides) from Ankarafantsika National Park, Madagascar. Helminthologia 2007; 44(4): 177-182. http://dx.doi. org/10.2478/s11687-007-0028-2.

Rueda-Almonacid JV, Carr JL, Mittermeier RA, Rodríguez-Mahecha JV, Mast RB, Vogt RC, et al. Las tortugas y los cocodrilianos de los países andinos del trópico. Bogotá: Editorial Panamericana, Formas e Impresos; 2007. (Serie de guias tropicales de campo. Conservación Internacional, n. 6.)
Thapar GS. Studies on the oxyurid parasites of reptiles. $J$ Helminthol 1925; 3(3-4): 83-150. http://dx.doi.org/10.1017/S0022149X0002945X.

Traversa D, Capelli G, Iorio R, Bouamer S, Cameli A, Giangaspero A. Epidemiology and biology of nematodofauna affecting Testudo hermanni, Testudo graeca and Testudo marginata in Italy. Parasitol Res 2005; 98(1): 14-20. PMid:16237575. http://dx.doi.org/10.1007/ s00436-005-0019-5. 